\title{
ВЛИЯНИЕ ВЕРХНЕ-ШИРВАНСКОГО КАНАЛА НА ИЗМЕНЕНИЕ ГИДРОГЕОЛОГО-МЕЛИОРАТИВНЫХ УСЛОВИЙ ШИРВАНСКОЙ СТЕПИ АЗЕРБАЙДЖАНА
}

\author{
Гюльмамедов Чингиз Джахангир оглы, \\ gcin56@mail.ru
}

Азербайджанское научно-производственное объединение «Гидротехника и Мелиорация», Азербайджанская республика, 1130, г. Баку, ул. И. Дадашова, 324.

\begin{abstract}
Актуальность исследования обусловлена необходимостью оценки изменений уровенного, гидрохимического режима грунтовых вод и темпов засоления почвогрунтов в связи со строительством и эксплуатацией Верхне-Ширванского канала Азербайджана и выявление закономерности изменения гидрогеолого-мелиоративных условий территории в зоне влияния упомянутого канала в многолетнем разрезе.

Цель: изучение изменения гидрогеолого-мелиоративных условий территории под влиянием антропогенных фракторов в зоне влияния Верхне-Ширванского канала после ввода его в эксплуатацию.

объекты: зона влияния Верхне-Ширванского канала Ширванской степи Азербайджанской Республики.

Методы. На основании результатов проведённых автором исследований по изменению среднемноголетнего уровня, минерализации грунтовых вод и темпов засоления почвогрунтов, а также собранных данных по этому направлению в период с 1980 по 2018 гг. в зоне влияния Верхне-Ширванского канала Ширванской степи были составлены карты глубины залегания уровня и минерализации грунтовых вод. На основании анализа и систематизации фрактических материалов по изменению гидрогеологических условий и засолённости почвогрунтов под влиянием антропогенных фракторов проведено гидрогеологомелиоративное районирование территории.

Результаты. В связи С эксплуатацией Верхне-Ширванского канала в зоне его влияния изменился уровень, минерализация, химический состав грунтовых вод, засолённость и химический состав почвогрунтов. В период с 1958 по 2018 гг. уровень грунтовых вод территории в связи с проведением оросительной мелиорации поднялся более чем на 4 м, а их минерализация, за счёт инфильтрации поверхностных и отвода минерализованных вод посредством дренажа, уменьшилась на 16 г/л. По всей площади зоны влияния Верхне-Ширванского канала режим подземных вод фрормируется за счёт орошения земель и дренажа. На основании анализа результатов проведённых исследований по изменению уровня, химического состава подземных вод, засоленности почвогрунтов и собранных архивных материалов проведено гидрогеолого-мелиоративное районирование территории. Выделена одна провинция - Куринский синклинорий, одна зона с климатом умеренно-тёпльх полупустьнь и сухих степей с сухим летом, три района и четыре подрайона. Первый район охватывает привершинную часть конусов выноса речных артерий. Коэфффициент фольтрации водовмещающих пород изменяется в пределах 4-10 м/сутки, минерализация грунтовых вод составляет 1-5 г/л, а глубина их залегания 6-10 м. Второй район охватьвает среднюю часть конуса выносов речных отложений, коэфффициент фильтрации пролювиальных отложений изменяется в пределах 3-5 м/сутки, минерализация грунтовых вод составляет 5-6 г/л, а глубина их залегания - 1,5-6,0 м. Третий район - это аллювиальная равнина реки Куры. Здесь коэфффициент фрильтрации водовмещающих пород достигает значений 1-10 м/сутки, минерализация грунтовых вод увеличивается до 1-50 г/л, а глубина их залегания составляет 1-3 м.
\end{abstract}

\section{Ключевые слова:}

Влияние, канал, подземные воды, минерализация, химический состав, уровень грунтовых вод, засоление, мелиоративное районирование.

\section{Введение}

Земельные и водные ресурсы Азербайджанской Республики - в ограниченном состоянии. Из 8,64 млн га территории 4,76 млн га (55,0 \%) пригодны для сельского хозяйства, из них 1,68 млн га $(39,4 \%)$ занимают пашни, целина и пастбища. Территория для сельскохозяйственных выгонов составляет 2,57 млн га $(54,1 \%$ от пригодных земель). Поверхностные водные ресурсы Республики по среднемноголетним данным составляют 22-24 млн м ${ }^{3}$, более $70 \%$ этого количества поступает из соседних республик в состоянии частичного загрязнения, а на долю ресурсов подземных вод приходится 9 млн м ${ }^{3}$ [1-3].

С начала 1950 г. в Азербайджане начался этап интенсивного орошения земель. В 1952 г. было сдано в эксплуатацию Варваринское водохранилище, а в 1953 г. - уникальное, многоцелевое (энергетика, орошение, рыболовство, туризм, спорт) Мингечаурское водохранилище. Наряду со строительством Мингечаурского водохранилища для обеспечения земель
Кура-Араксинской степи поливной водой в 1955 г. был построен и сдан в эксплуатацию ВерхнеКарабахский канал, в 1958 г. - Верхне-Ширванский канал (ВШК), а в 1960 г. - Главный Муганский канал и магистральный канал имени Сабира. В 1960 г. общая площадь орошаемых земель Республики составляла 950 тыс. га, а в настоящее время - 1428 тыс. га [2].

Под влиянием антропогенных факторов изменился химический состав, состояние и условия формирования, зоны питания, режим подземных вод территории $[3,4]$. Изучение изменения состава и состояния подземных вод под влиянием антропогенных факторов и формирование гидрогеолого-мелиоративных условий территории на этом фоне является актуальной задачей перед современной гидрогеологией [5-12].

\section{Материалы и методика исследования}

Территория Ширванской степи охватывает левый берег реки Куры от Мингечаурского водохранилища на северозападе до Агджикабульского района на юго-востоке. 
В границах степного ландшафта находятся территории Евлахского, Агдашского, Геокчайского, Исмаиллинского, Уджарского, Зардобского, Кюрдамирского, Ахсуинского, Шемахинского и Агджикабульского административных районов.

В Ширванской степи 450 тыс. га площади пригодны для орошения, но из-за нехватки воды только на 225 тыс. га площади проводится орошение, из них 125,6 тыс. га (56 \%) - за счёт ВШК [2-4].

ВШК берёт своё начало от Мингечаурского водохранилища. Назначение ВШК - обеспечивать орошаемой водой территорию Ширванской степи. В настоящее время канал ограничен р. Ахсучай, но в дальнейшем его планируется довести до г. Агджикабул. Проектная длина канала составляет 122,8 км, максимальный дебит достигает $78 \mathrm{~m}^{3} /$ сек. Канал обеспечивает водой орошаемые площади на территориях Евлахского, Агдашского, Геокчайского, Уджарского, Кюрдамирского и Ахсуинского районов. Ширина по дну канала колеблется от 2,5 до 14,0 м, глубина - от 2,5 до 6,0 м. Большая часть канала имеет земляное русло. Бетонная или железобетонная облицовка вы- полнена только в начальной части канала и на участках пересечения с речными артериями (всего 27 км). В связи с этим происходят большие потери воды из канала. За длительный период беспрерывной эксплуатации, продолжающийся более 60 лет, канал утратил часть своих функций и потери воды из него увеличились, а коэффициент полезного действия (КПД) снизился. Среднемноголетние потери воды из канала составляют 324 млн м ${ }^{3} /$ год $[4,6,10]$. С 2000 по 2016 гг. (за 17 лет) среднемноголетний объём воды, поступивший из Мингечаурского водохранилища в русло канала составил 1229,0 млн м ${ }^{3}$ (табл. 1), а на распределители подано 905,1 млн м ${ }^{3}$ (табл. 2). За этот период КПД составил $74 \%(905,1 / 1229,1=0,74)$, а среднегодовая потеря воды из ВШК достигла 324,0 млн м ${ }^{3}$ $(1229,1-905,1=324,0)$.

Все это доказывает, что каналу требуется реконструкция. Если после реконструкции КПД повысится до 0,95, то потеря воды из канала сократится до 61,5 млн м $\left.{ }^{3}(1229,1 \times 0,95)=61,5\right)$. Экономия воды составит 262,5 млн м ${ }^{3}(324,0-61,5=262,5)$ что позволит дополнительно оросить 30,0 тыс. га земель.

Таблица 1. Объёмы (млн $\left.\mathrm{M}^{3}\right)$ и расходы $\left(\mathrm{M}^{3} / \mathrm{c}\right)$ воды, поступивщей из Мингечаурского водохранилища за период с 2000 по 2016 г2. в русло Верхне-Ширванского канала [4, 6]

Table 1. Volumes (million $\left.\mathrm{m}^{3}\right)$ and flow rates $\left(\mathrm{m}^{3} / \mathrm{s}\right)$ of water taken from the Mingechevir reservoir for 2000-2016 with Verkhne-Shirvan canal [4, 6]

\begin{tabular}{|c|c|c|c|c|c|c|c|c|c|c|c|c|c|c|c|c|c|c|}
\hline $\begin{array}{c}\text { Год } \\
\text { Yеar }\end{array}$ & 2000 & 2001 & 2002 & 2003 & 2004 & 2005 & 2006 & 2007 & 2008 & 2009 & 2010 & 2011 & 2012 & 2013 & 2014 & 2015 & 2016 & $\begin{array}{c}\text { Cреднее } \\
\text { Average }\end{array}$ \\
\hline $\begin{array}{c}\mathrm{M}^{3} / \mathrm{c} \\
\mathrm{m}^{3} / \mathrm{s}\end{array}$ & 32,83 & 35,00 & 37,00 & 37,83 & 43,50 & 48,92 & 46,08 & 46,17 & 37,50 & 33,83 & 36,25 & 35,00 & 38,67 & 36,67 & 41,83 & 39,00 & 35,91 & 38,94 \\
\hline $\begin{array}{c}\text { млн } \\
\text { million }^{3}\end{array}$ & 1038,0 & 1104,0 & 1167,1 & 1193,4 & 1376,0 & 1543,0 & 1453,0 & 1456,0 & 1186,0 & 1067,2 & 1143,4 & 1104,0 & 1223,0 & 1156,0 & 1319,0 & 1230,2 & 1135,0 & 1229,0 \\
\hline
\end{tabular}

Таблица 2. Объёмы (млн $\left.м^{3}\right)$ и расходы $\left(\mathrm{M}^{3} / \mathrm{c}\right)$ воды, поданной на оромение Верхне-Ширванским каналом за 2000-2016 г2. [4, 6]

Table 2. Volumes (million $\left.\mathrm{m}^{3}\right)$ and flow rates $\left(\mathrm{m}^{3} / \mathrm{s}\right)$ of water supplied for irrigation from the Verkhne-Shirvan canal for 2000-2016 [4, 6]

\begin{tabular}{|c|c|c|c|c|c|c|c|c|c|c|c|c|c|c|c|c|c|c|}
\hline $\begin{array}{c}\text { Год } \\
\text { Year }\end{array}$ & 2000 & 2001 & 2002 & 2003 & 2004 & 2005 & 2006 & 2007 & 2008 & 2009 & 2010 & 2011 & 2012 & 2013 & 2014 & 2015 & 2016 & $\begin{array}{c}\text { Cреднее } \\
\text { Average }\end{array}$ \\
\hline $\begin{array}{c}\mathrm{m}^{3} / \mathrm{c} \\
\mathrm{m}^{3} / \mathrm{s}\end{array}$ & 23,22 & 25,23 & 27,24 & 27,00 & 34,10 & 35,92 & 34,93 & 32,42 & 24,98 & 25,66 & 24,47 & 24,98 & 28,43 & 29,20 & 31,23 & 30,08 & 28,44 & 28,68 \\
\hline $\begin{array}{c}\mathrm{M}^{\mathrm{N}} \mathrm{m}^{3} \\
\text { million }^{3}\end{array}$ & 734,3 & 795,6 & 859,2 & 851,4 & 1078,4 & 1132,6 & 1102,4 & 1022,3 & 790,10 & 890,3 & 771,6 & 787,8 & 899,2 & 920,8 & 984,9 & 948,7 & 899,4 & 905,11 \\
\hline
\end{tabular}

Таблица 3. КПД и водные потери в ирригаџионных системах Республики в различные годы [4, 10]

Table 3. Efficiency and water losses in the irrigation systems of the Republic in different years [4, 10]

\begin{tabular}{|c|c|c|c|}
\hline $\begin{array}{c}\text { Год } \\
\text { Year }\end{array}$ & $\begin{array}{c}\text { Орошаемая } \\
\text { площадь, тыс. га } \\
\text { Irrigated area, } \\
\text { thousand ha }\end{array}$ & $\begin{array}{c}\text { КПД системы } \\
\text { System } \\
\text { efficiency }\end{array}$ & $\begin{array}{c}\text { Фильтрационные } \\
\text { потери, км } \\
\text { Filtration losses } \\
\mathrm{km}^{3}\end{array}$ \\
\hline 1915 & 535 & 0,38 & 1,3 \\
\hline 1930 & 550 & 0,45 & 1,5 \\
\hline 1940 & 726 & 0,53 & 1,7 \\
\hline 1950 & 810 & 0,60 & 2,1 \\
\hline 1960 & 950 & 0,60 & 2,5 \\
\hline 1970 & 1024 & 0,64 & 2,8 \\
\hline 1980 & 1207 & 0,65 & 3,5 \\
\hline 1985 & 1263 & 0,66 & 6,0 \\
\hline 1990 & 1410 & 0,68 & 5,9 \\
\hline 1995 & 1453 & 0,73 & 5,5 \\
\hline 2000 & 1426 & 0,78 & 4,4 \\
\hline 2005 & 1426 & 0,80 & 4,3 \\
\hline 2010 & 1426 & 0,82 & 4,3 \\
\hline 2018 & 1426 & 0,85 & 4,2 \\
\hline
\end{tabular}

Результаты исследований, проведённых в 1960-2018 гг. ОАО «Мелиорация и водное хозяйство Азербайджана» и Научно-производственным объединением гидротехники и мелиорации Азербайджана, показывают, что поступившая из Мингечаурского водохранилища, при транспортировке по руслу ВШК часть воды фильтруется в почвогрунт (табл. 3), а часть испаряется. Испарение с водной поверхности на один км протяженности канала рассчитывается по формуле:

$$
\mathrm{E}=0,011 \mathrm{x}_{\mathrm{e}} \cdot(\mathrm{b}+2 \mathrm{mh}), \mathrm{m}^{3} / \mathrm{c} \text { на } 1 \mathrm{\kappa м},
$$

где $\mathrm{E}$ - испарение с водной поверхности, $\mathrm{m}^{3} / \mathrm{c} ; \mathrm{x}_{\mathrm{e}}-$ верхняя ширина уреза канала, м; b - ширина дна канала, м; $\mathrm{h}$ - мощность воды в канале, м; $\mathrm{m}$ - коэффициент откоса канала; $(b+2 m h)$ - ширина канала по верху, м.

Фильтрационные воды поступают в грунтовые минерализованные воды и поднимают их уровень, в связи с чем повышается испарение с поверхности грунтовых вод (ГВ). В результате происходит вто- 
ричное засоление почвы, уменьшается влажность почвы, снижается плодородие сельскохозяйственных культур, нарушается экологическое равновесие, повышаются материальные расходы на реконструкцию и рекультивацию земель.

После реконструкции канала в ближайшие годы по проектам института «Азгипроводхоз» Азербайджана для полного обеспечения территории водой и освоения ещё 45952 га земель Шемахинского и Агджикабульского районов (табл. 4) канал будет продолжен до 67,72 км, итого длина будет составлять 190 км, а расход 180 м³/с. По этому проекту для уменьшения потерь из канала предусматривается снабдить откосы канала геомембранным железобе- тонным покрытием. В этом случае фильтрационные потери будут составлять $1,5-2,0 \%$, потери на испарение $-1,5 \%$, технические потери - 1,0-1,5\%.

Для уменьшения и предотвращения фильтрационных потерь из ирригационных каналов можно провести следующие мероприятия: добиться более эффективного использования водных ресурсов, повысить КПД каналов, внедрить систему управления для сохранения уровня грунтовых вод (УГВ), что в результате приведёт к предотвращению повторного засоления и улучшению мелиоративного состояния почвогрунтов, повышению урожайности сельскохозяйственных культур, сохранению экологической стабильности и защите окружающий среды $[2,6,10]$.

Таблица 4. Орошаемые площзади по административным районам до и после реконструкции Верхне-Ширванского канала в зоне его влияния [2]

Table 4. Irrigated areas by administrative districts before and after the reconstruction of the Verkhne-Shirvan canal in the zone of its influence [2]

\begin{tabular}{|c|c|c|c|c|c|c|}
\hline \multirow{4}{*}{$\begin{array}{c}\text { Районы } \\
\text { Areas }\end{array}$} & \multirow{2}{*}{\multicolumn{2}{|c|}{$\begin{array}{c}\text { Орошаемые Верхне- } \\
\text { Ширванским каналом } \\
\text { площади } \\
\text { Areas irrigated with the } \\
\text { Verkhne-Shirvan canal }\end{array}$}} & \multicolumn{4}{|c|}{ В том числе/Including } \\
\hline & & & \multicolumn{2}{|c|}{$\begin{array}{c}\text { площади, орошаемые Верхне-Ширванским } \\
\text { каналом в настоящее время } \\
\text { areas currently irrigated } \\
\text { with the Verkhne-Shirvan canal }\end{array}$} & \multicolumn{2}{|c|}{$\begin{array}{c}\text { новые площади, орошаемые } \\
\text { Верхне-Ширванским каналом } \\
\text { new areas irrigated } \\
\text { with the Verkhne-Shirvan canal }\end{array}$} \\
\hline & \multicolumn{6}{|c|}{ га/ha } \\
\hline & $\begin{array}{c}\text { Брутто } \\
\text { Gross }\end{array}$ & $\begin{array}{c}\text { Hетто } \\
\text { Net }\end{array}$ & $\begin{array}{c}\text { Брутто } \\
\text { Gross }\end{array}$ & $\begin{array}{l}\text { Нетто } \\
\text { Net }\end{array}$ & $\begin{array}{c}\text { Брутто } \\
\text { Gross }\end{array}$ & $\begin{array}{c}\text { Нетто } \\
\text { Net }\end{array}$ \\
\hline $\begin{array}{l}\text { Евлахский } \\
\text { Evlakh }\end{array}$ & 10834 & 9751 & 7692 & 6923 & 3142 & 2828 \\
\hline $\begin{array}{c}\text { Агдашский } \\
\text { Agdash }\end{array}$ & 14529 & 13076 & 8893 & 8004 & 5636 & 5072 \\
\hline $\begin{array}{c}\text { Геокчайский } \\
\text { Geokchay }\end{array}$ & 23546 & 21191 & 16036 & 14432 & 7510 & 6759 \\
\hline $\begin{array}{l}\text { Исмаиллинский } \\
\text { Ismayilli }\end{array}$ & 2497 & 2247 & 2497 & 2247 & - & - \\
\hline $\begin{array}{c}\text { Уджарский } \\
\text { Ujar }\end{array}$ & 34644 & 31179 & 26658 & 23902 & 7986 & 7187 \\
\hline $\begin{array}{c}\text { Зардобский } \\
\text { Zardob }\end{array}$ & 8263 & 7437 & 8263 & 7437 & - & - \\
\hline $\begin{array}{c}\text { Кюрдамирский } \\
\text { Kurdamir }\end{array}$ & 69544 & 62590 & 37072 & 33365 & 32472 & 29225 \\
\hline $\begin{array}{c}\text { Ахсуинский } \\
\text { Akhsu }\end{array}$ & 41748 & 37619 & 26774 & 24097 & 15024 & 13522 \\
\hline $\begin{array}{c}\text { Агджикабулский } \\
\text { Agdjigabul }\end{array}$ & 33482 & 30134 & 2158 & 1942 & 31324 & 28192 \\
\hline $\begin{array}{l}\text { Шемахинский } \\
\text { Shemakhi }\end{array}$ & 18090 & 16281 & 3462 & 3116 & 14628 & 13165 \\
\hline Итого/Total & 257227 & 231505 & 139505 & 125555 & 117722 & 105950 \\
\hline
\end{tabular}

Многолетние наблюдения показывают, что если проектные максимальные расходы канала составляли $78 \mathrm{~m}^{3} / \mathrm{c}$, а среднемноголетние - 35,4, то после реконструкции предусматривается повысить максимальный расход канала до $180 \mathrm{~m}^{3} / \mathrm{c}$, тогда среднегодовой расход будет $91 \mathrm{~m}^{3} / \mathrm{c}$. За год расход составит:

$91 \mathrm{~m}^{3} / \mathrm{c} \cdot 86400 \mathrm{c} \cdot 365$ суток$=2870$ млн м ${ }^{3}$.

Территория зоны влияния ВШК считается сухой предгорной зоной, здесь только 12 \% площади можно отнести к участкам с достаточной степенью естественной дренированности, а остальная часть является слабо дренированной или не дренированной. Литологический состав геологического разреза представлен тяжелыми глинами, характерными для Ширванской степи $[6,7]$. По водопроводимости почвы территория разделяется на три группы: почвы с ко- эффициентом фильтрации больше 0,30 м/сутки; слабо водопроницаемые почвы с коэффициентом фильтрации - 0,05-0,30 м/сутки; почвы с коэффициентом фильтрации меньше 0,05 м/сутки [7, 8]. Величина гумуса 0,50-2,07 \%, карбонатность 11-17 \%, pH 8,2-8,8. Общая площадь орошаемых земель составляет 230,18 тыс. га (табл. 4), из них 153,3 тыс. га, или 66,6 \% (112,8 закрытые, 40,5 открытые), площади снабжены коллекторно-дренажной сетью (КДС). Состояние оросительных каналов и КДС открытого типа и находятся в земляном русле. С 1971 по 1991 гг. отдельные части канала покрывались бетонной облицовкой.

Дренированные территории обслуживают три магистральных коллектора общей длиной 308 км (Верхне-Ширванский коллектор, Нижне-Ширванский коллектор-1, Нижне-Ширванский коллектор-2) при дренажном модуле 0,10-0,25 л/с га. 
За год в зону влияния ВШК подаётся 1,41 км $^{3}$ воды, а с территории отводится 0,298 км$^{3}$ воды. По данным инвентаризации, проведённой нами в разное время, можно сказать, что техническое состояние КДС неудовлетворительное. Минерализация воды, поданной ВШК на орошаемые территории, изменяется в пределах 0,4-1,2 г/л (в среднем 0,67 г/л), а минерализация воды Верхне-Ширванского коллектора составляет 2,5-7,3 г/л (в среднем 3,59 г/л) (табл. 5).

Таблица 5. Расходы и минерализация воды, поступающей по ВШК и отводящейся по Главному Ширванскому коллектору с территории Ширванской степи [3, 10, 12]

Table 5. Discharge of water and its mineralization entering along the Verkhne-Shirvan canal and discharging from the Main Shirvan collectors from the territory of the Shirvan steppe $[3,10,12]$

\begin{tabular}{|c|c|c|}
\hline \multirow{3}{*}{$\begin{array}{l}\text { Верхне- } \\
\text { Ширванский } \\
\text { канал } \\
\text { Verkhne- } \\
\text { Shirvan canal }\end{array}$} & $\begin{array}{l}\text { Среднегодовая минерализация, г/л } \\
\text { Average annual mineralization, g/l }\end{array}$ & 0,675 \\
\hline & \begin{tabular}{|l|} 
Расход воды, $\mathrm{m}^{3} / \mathrm{c}$ \\
Water consumption, $\mathrm{m}^{3} / \mathrm{s}$
\end{tabular} & 45,050 \\
\hline & \begin{tabular}{|l} 
Объём воды поступающий \\
на территорию, км \\
Volume of water entering the territory, $\mathrm{km}^{3}$ \\
\end{tabular} & 1,410 \\
\hline \multirow{3}{*}{$\begin{array}{l}\text { Главный } \\
\text { Ширванский } \\
\text { коллектор } \\
\text { Main Shirvan } \\
\text { collector }\end{array}$} & \begin{tabular}{|l|} 
Среднегодовая минерализация, г/л \\
Average annual mineralization, g/l \\
\end{tabular} & 3,588 \\
\hline & \begin{tabular}{|l|} 
Расход воды, $\mathrm{m}^{3} / \mathrm{c}$ \\
Water consumption, $\mathrm{m}^{3} / \mathrm{s}$ \\
\end{tabular} & 10,100 \\
\hline & $\begin{array}{l}\text { Объём воды, отводящийся } \\
\text { с территории, км } \\
\text { Volume of water discharged } \\
\text { from the territory, } \mathrm{km}^{3}\end{array}$ & 0,298 \\
\hline \multicolumn{2}{|c|}{$\begin{array}{l}\text { Водоотвод с зоны влияния Верхне Ширванского канала, \% } \\
\text { Drainage from the zone of influence } \\
\text { of the Verkhne-Shirvan canal, \% }\end{array}$} & 0,211 \\
\hline \multicolumn{2}{|c|}{$\begin{array}{l}\text { Мелиоративный индекс в зоне влияния } \\
\text { Верхне-Ширванского канала } \\
\text { Reclamation index in the zone of influence } \\
\text { of the Verkhne-Shirvan canal }\end{array}$} & 5,28 \\
\hline
\end{tabular}

На основании результатов исследований, проведённых автором в 1980-2018 гг., по измерению уровня грунтовых вод в наблюдательных скважинах и анализов материалов «Национальной ГеологоРазведочной Службы» Министерства экологии и природных ресурсов Азербайджанской Республики по прогнозированию уровенного режима грунтовых вод установлено, что на тех участках, где уровень грунтовых вод залегает глубже 10 м, за счёт фильтрации на орошаемых площадях и фильтрационных потерь из каналов через 3-7 лет ГВ будут подниматься до поверхности земли и в результате может произойти вторичное засоление почвы.

Современное состояние почвы определяется по степени засоления, количеству токсичных солей и типу засоления. Степень засоления по плотному остатку изменяется от 0,1 до 3,0 и более $\%$. Допустимая степень засоления зависит от типа засолённости почв. Допустимый предел засоления для всех типов менее $0,3 \%$ по плотному остатку. Токсичность солей зависит от их типа. Самой токсичной солью является $\mathrm{NaHCO}_{3}$ (сода), нетоксичной солью - $\mathrm{CaSO}_{4}$. Тип засоления бывает: $\mathrm{Cl}-\mathrm{SO}_{4}, \mathrm{SO}_{4}, \mathrm{SO}_{4}-\mathrm{Cl}, \mathrm{HCO}_{3}$, содовые $[2,10,12-16]$.

\section{Результаты исследования}

Изучением гидрогеологических условий Ширванской степи занимались Ф.Ш. Алиев, Ф.П. Саваренский, В.А. Приклонский, И.Й. Давыдов, Г.Ю. Исрафилов, Е.Р. Фиалко, В.А. Листенгартен, А.К. Алимов, А.А. Мусаев, Н.В. Роговская, З.А. Абдуллаев, С.М. Эфендиева, Д.Ю. Исрафилов, А.Б. Алекперов, Ч.Д. Гюльмамедов и др.

В 1950 г. гидрогеологические и ирригационномелиоративные работы в Азербайджане были еще слабо развиты. В то время в Ширванской степи глубина залегания УГВ составляла $5-10$ м $[1,10,12]$ и на больших глубинах подземные воды были отнесены к типу гидрокарбонатно-натриевых, а ближе к поверхности земли их анионный состав изменялся на хлоридно-сульфатный и сульфатно-хлоридный $[1,12,14$, 17-22]. При минерализации воды до 1 г/л из анионов ведущую роль играют гидрокарбонаты, а из катионов - натрий и кальций, в редких случаях - магний $[6,15,16]$. В составе грунтовых вод при минерализации 10-15 г/л концентрация гидрокарбонатов уменьшается, а хлор-иона и сульфат-иона увеличивается. В этих водах концентрация натрия и магния больше, чем калия. В грунтовых водах при минерализации 50-100 г/л и более уменьшается содержание иона сульфата, увеличивается концентрация хлора, а иногда наоборот $[3,18]$. На исследуемой территории в связи с проведением ирригационных мероприятий изменился многолетний и сезонный уровень и гидрохимический режим ГВ. Этот процесс продолжается до настоящего времени.

Под влиянием антропогенных факторов в течение 60 лет УГВ поднялся более чем на 4,0 м. В 1962 г. на большую часть площади Ширванской степи (около $84,0 \%$ подземные воды залегали на глубине $0-5,0$ м, а в 1970-1980 гг. площадь территорий с глубиной залегания подземных вод 0-3,0 м увеличилась до $90 \%$. Поднятие УГВ продолжалось до 1995 г. с различной интенсивностью в связи с отсутствием или плохой работой КДС, что сопровождалось продолжением процесса засоления почвогрунтов. В последующие годы в связи со строительством КДС и интенсификацией процессов испарения с поверхности ГВ, расположенных ближе к поверхности земли, глубины залегания уровня подземных вод постепенно стабилизировались (табл. 6).

Расширение орошаемых площадей и увеличение водоподачи на массивах орошения приводит в некоторых случаях к ухудшению мелиоративного состояния земель. Это заставляет со всей серьёзностью заняться вопросом прогнозирования режима ГВ этих земель.

Соответственно режиму УГВ формируется и их минерализация [3, 9, 11, 18-22]. В течение 60 лет минерализация ГВ уменьшилась примерно на 16,0 г/л. В 1950-1960 гг. минерализация ГВ изменилась в пределах от 1,0 до 150 г/л. Начиная с 1960 г. в связи с антропогенными факторами началось постепенное уменьшение минерализации ГВ. В период с 2000 по 2018 гг. она уменьшилась до $15,0-16,0$ г/л (табл. 7). Понижение минерализации связано не только с инфильтрацией орошаемых вод $[1,6,18,20]$, 
но также с функционированием на территории КДС. Для отвода коллекторно-дренажных вод с 143,3 тыс. га площади в 1965 г. был построен и сдан в эксплуатацию Главный Ширванский коллектор с проектным расходом 44 $\mathrm{m}^{3} / \mathrm{c}$, а в 1984-1987 гг. коллектор был реконструирован, и его водопропускная способность повысилась до 72,0 м $3 / \mathrm{c}$.

Таблица 6. Распределение площзадей Ширванской степи по глубине залегания грунтовых вод в различные годы, в \% от общей площади [10]

Table 6. Distribution of the Shirvan steppe area by groundwater depth, \% of the total area at different times [10]

\begin{tabular}{|c|c|c|c|c|c|c|c|}
\hline \multirow{2}{*}{$\begin{array}{l}\text { Год } \\
\text { Year }\end{array}$} & \multicolumn{6}{|c|}{$\begin{array}{c}\text { Глубина залегания уровня грунто- } \\
\text { вых вод, м } \\
\text { Depth of groundwater level, m }\end{array}$} & \multirow{2}{*}{$\begin{array}{c}\text { Осреднённое значе- } \\
\text { ние глубины залега- } \\
\text { ния уровня грунтовых } \\
\text { вод, м } \\
\text { Average value of the } \\
\text { groundwater level } \\
\text { depth, m }\end{array}$} \\
\hline & $\stackrel{0}{\vec{v}}$ & $\stackrel{n}{i}$ & $\begin{array}{l}0 \\
i \\
n \\
n\end{array}$ & $\begin{array}{l}n \\
i \\
0 \\
i\end{array}$ & $\begin{array}{l}\stackrel{0}{i} \\
i \\
i\end{array}$ & $\stackrel{0}{\hat{\lambda}}$ & \\
\hline 1930 & 4,4 & 2,7 & 3,1 & 10,2 & 25,9 & 63,7 & 6,04 \\
\hline 1950 & 5,6 & 3,0 & 3,5 & 11,5 & 26,2 & 50,2 & 5,78 \\
\hline 1970 & 16,2 & 15,1 & 16,0 & 23,3 & 15,1 & 13,3 & 2,43 \\
\hline 1980 & 27,2 & 17,1 & 15,0 & 26,3 & 8,3 & 6,2 & 2,29 \\
\hline 1990 & 21,8 & 21,1 & 18,5 & 29,2 & 6,3 & 3,1 & 2,04 \\
\hline 2010 & 20,5 & 20,8 & 19,7 & 28,2 & 7,3 & 2,5 & 1,80 \\
\hline 2018 & 15,1 & 22,1 & 23,8 & 29,4 & 6,8 & 2,8 & 1,82 \\
\hline
\end{tabular}

Таблица 7. Минерализачия грунтовых вод Ширванской степи на середину мая [6, 10]

Table 7. Mineralization of groundwater in the Shirvan steppe in mid-May [6, 10]

\begin{tabular}{|c|c|c|c|c|c|c|c|c|}
\hline \multirow[t]{2}{*}{\begin{tabular}{|l} 
Год \\
Year
\end{tabular}} & \multicolumn{7}{|c|}{$\begin{array}{l}\text { Распределение площадей (в \% от расчёт- } \\
\text { ной) по градациям минерализации грун- } \\
\text { товых вод (г/л) } \\
\begin{array}{c}\text { Distribution of areas (in \% of the calculated) } \\
\text { by gradations of groundwater salinity (g/l) }\end{array}\end{array}$} & \multirow{2}{*}{\begin{tabular}{|c|} 
Средневзвешен- \\
ное значение \\
минерализации \\
грунтовых вод, \\
м \\
Weighted \\
average value of \\
groundwater \\
salinity, m
\end{tabular}} \\
\hline & $<1$ & $1-3$ & $3-5$ & $5-10$ & $10-2$ & | & $>50$ & \\
\hline 30 & 6,2 & 8 & 13,0 & & & & 26,8 & \\
\hline 50 & 4,3 & 6 & 9 & 1 & 17, & 18,3 & 29, & \\
\hline 960 & 2,0 & 4 & 6,5 & 11 & 18, & 20,2 & 32,7 & \\
\hline 970 & 3,9 & 5,2 & 7,2 & 1. & 17,7 & 19,4 & 31 , & \\
\hline 980 & 9,7 & 15,5 & 15,0 & 17,1 & 8 & 10,9 & 19,0 & 1,4 \\
\hline 990 & 13,3 & 16,4 & 17,2 & 18,4 & 13,4 & & 14,5 & \\
\hline 00 & 14,8 & 28, & 16 & 17 & 11,6 & & 10,3 & \\
\hline 10 & 12,3 & 30,4 & 18,6 & 17 & 0,3 & 4, & 6,6 & \\
\hline 018 & \begin{tabular}{|l|}
9,1 \\
\end{tabular} & 29,6 & 21,1 & 20,3 & 10,2 & 3,5 & 6,2 & 15,5 \\
\hline
\end{tabular}

По нашим расчётам [3, 10] с 1963 г. по настоящее время с территории равнины дренажными водами ежегодно выносится более 3,2 млн т солей, что приводит к сокращению площади с высокой минерализацией грунтовых вод.

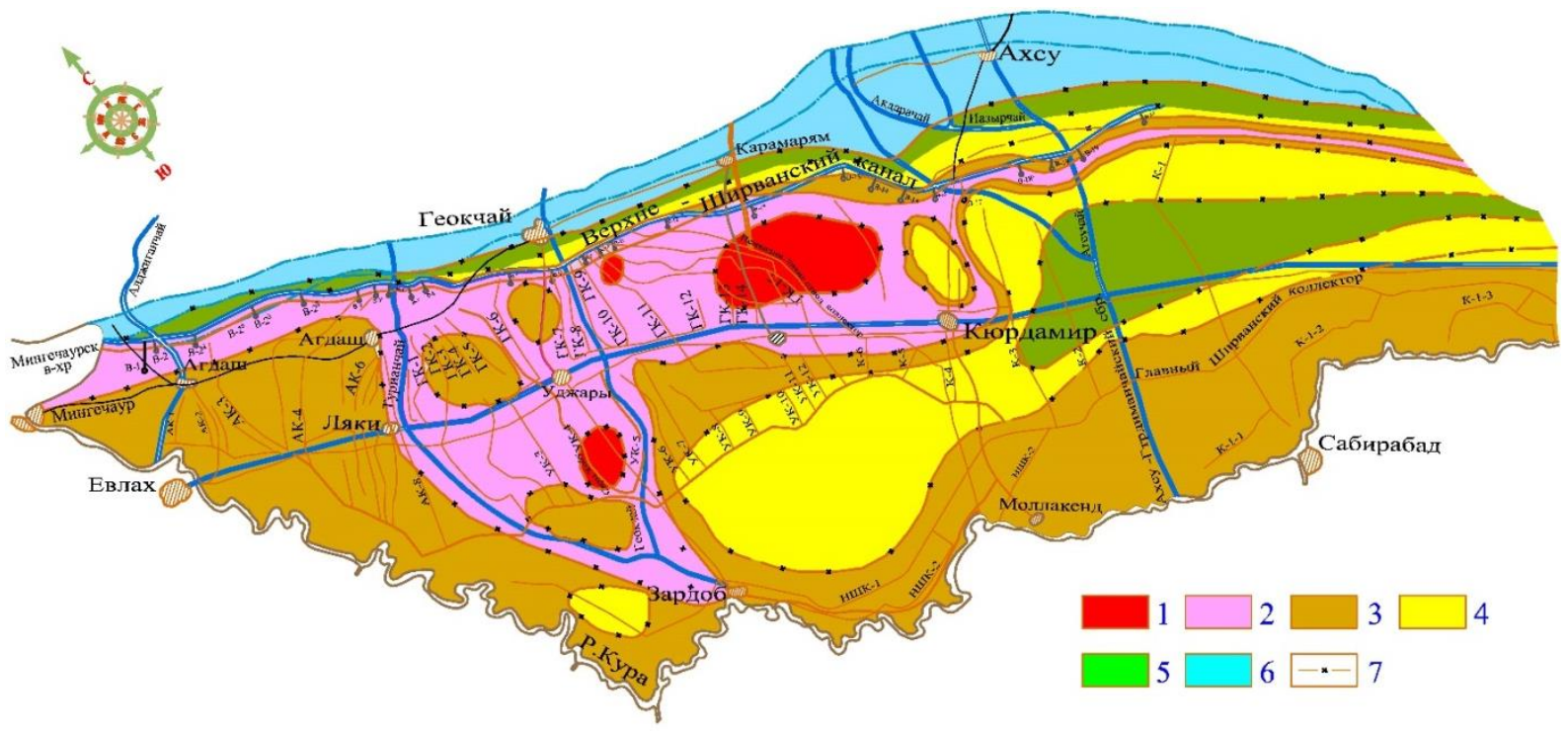

Рис. 1. Схематическая карта глубин залегания уровня грунтовых вод Ширванской степи (по состоянию на 20.05.2018 г., составлена Ч.Д. Гюльмамедовым; М. 1:100000): уровень грунтовых вод, м: 1) <1,0; 2) 1,0-1,5; 3) $1,5-2,0$; 4) 2,0-2,5; 5) 2,5-3,0; 6) >3,0; 7) гранищы участков с различными глубинами залегания уровня грунтовых вод

Fig. 1. Schematic map of the groundwater level depth of the Shirvan steppe (as of 20.05.2018, composed by Ch.D. Gulmammadov; S. 1:100000): groundwater level, m: 1) <1,0; 2) 1,0-1,5; 3) 1,5-2,0; 4) 2,0-2,5; 5) 2,5-3,0; 6) >3,0; 7) boundaries of sites with different depths of groundwater occurrence

\section{Гидрогеолого-мелиоративное районирование}

Для научного обоснования проектирования ирригационно-мелиоративных мероприятий широко используется гидрогеолого-мелиоративное районирование, которым занимались многие исследователи $[6,10$, $12,17,19,20,23,24]$. При рассмотрении работ различных исследователей по вопросам методики гидро- геолого-мелиоративного районирования выявляется картина определенной эволюции мелиоративного анализа, намечаются различные подходы к разрешению проблемы в целом. Первый из них характеризуется стремлением организовать учёт земельных фондов, в том числе земель вторичного засоления, и составить кадастры орошаемых земель. 


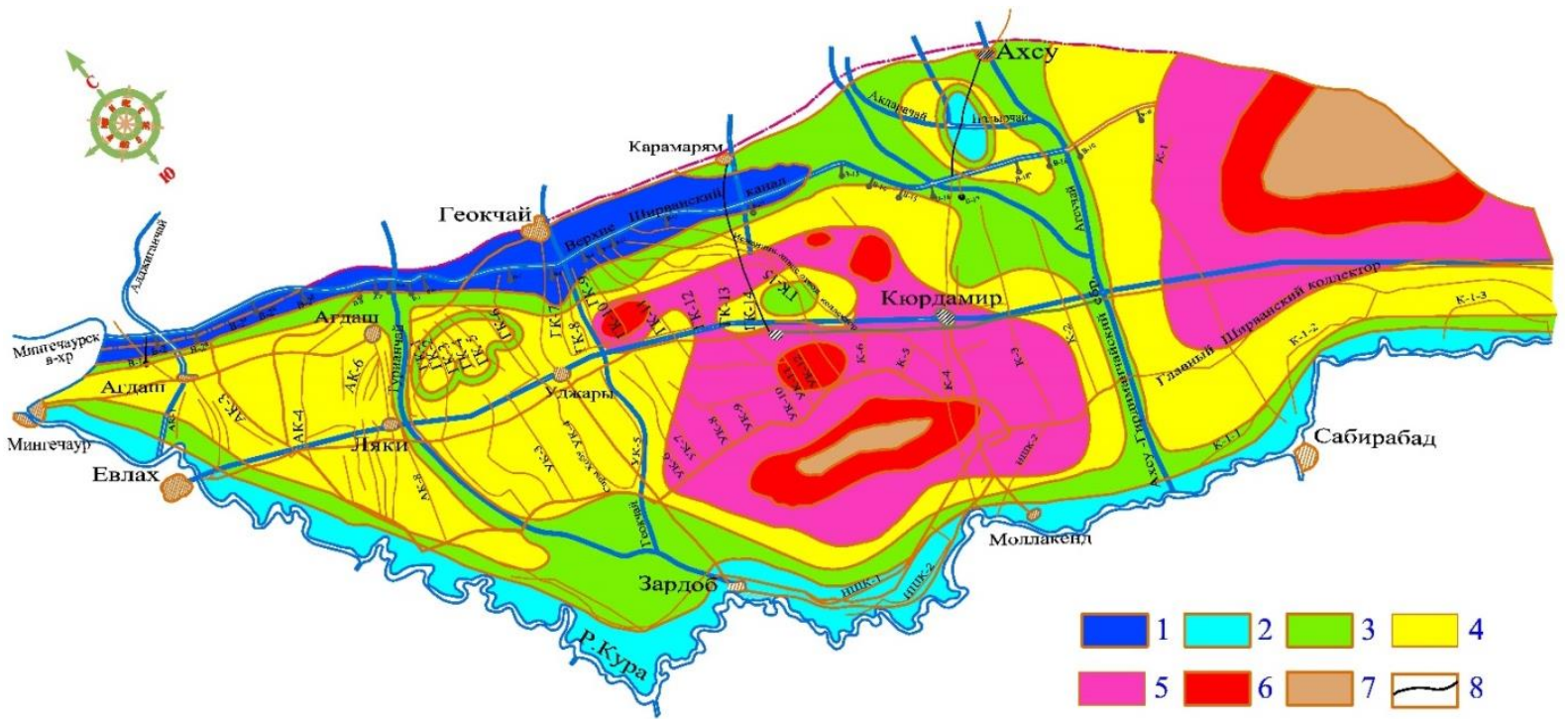

Pис. 2. Схематическая карта общей минерализачии грунтовых вод Ширванской степи (по состоянию на 20.05.2018 г., составлена Ч.Д. Гюльмамедовым; М. 1:100000): минерализация грунтовых вод, г/л: 1) >1; 2) 1-3; 3) 3-5; 4) 5-10; 5) 10-25; 6) 25-50; 7) >50; 8) гранищы между участками с разной минерализаџией грунтовых вод

Fig. 2. Schematic map of the general mineralization of groundwater in the Shirvan steppe (as of 20.05.2018, composed by Ch.D. Gulmammadov; S. 1:100000): mineralization of groundwater, g/l;1) >1; 2) 1-3; 3) 3-5; 4) 5-10; 5) 10-25; 6) 25-50;7) >50; 8) boundaries between areas with different groundwater salinity

Второй подход- выяснение причин засоления почв при орошении, что служит основой для разработки системы мелиоративных мероприятий. На данном этапе разработаны принципы районирования орошаемых территорий в зависимости от физикогеографических условий. Третий подход характеризуется стремлением классифицировать орошаемые территории с точки зрения условий строительства ирригационных систем.

На основании результатов проведённых автором исследований и анализа данных бывшего Азгеологоуправления (ныне «Национальные ГеологоРазведочные Службы» Министерства экологии и природных ресурсов Азербайджанской Республики) и Гидрогеолого-мелиоративной экспедиции (ныне «Гидрогеолого-мелиоративной службы» при ОАО «Мелиорация и водное хозяйство») проведено гидрогеолого-мелиоративное районирование и рассчитаны площади распространения каждого района.

Нами при выделении таксономических единиц гидрогеолого-мелиоративного районирования в качестве основы принята классификация Д.М. Каца [24]. При этом выделена провинция - по признакам отнесения к определённой геолого-тектонической структуре; зона - по почвенно-климатическим признакам; районы - по геоморфологическим элементам и литологическому строению толщи до водоупора; подрайоны - по типу, степени засолённости почвогрунтов и режиму грунтовых вод.

Оценка гидрогеологических условий применительно к обоснованию мелиоративного строительства связана с детализацией существующего гидрогеологического районирования. За основной показатель нами принимается структура водно-солевого баланса. Выделяется одна провинция - Куринский синклино- рий, одна зона с климатом умеренно-тёплых полупустынь и сухих степей с сухим летом, три района, четыре подрайона (табл. 8).

Таблица 8. Основные показатели гидрогеологомелиоративных районов и подрайонов

Table 8. Main indicators of hydrogeological reclamation areas and subareas

\begin{tabular}{|c|c|c|c|c|c|}
\hline \multirow[b]{2}{*}{ 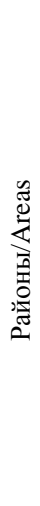 } & \multirow[b]{2}{*}{ 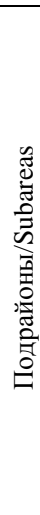 } & \multicolumn{4}{|c|}{$\begin{array}{c}\text { Основные осреднённые характеристики за 1950-2018 гг. } \\
\text { Main averaged characteristics for } 1950-2018\end{array}$} \\
\hline & & 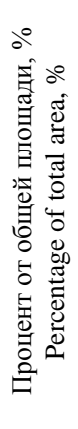 & 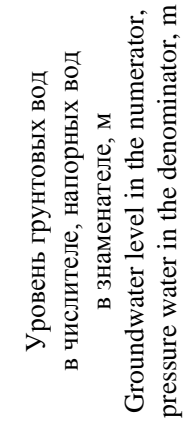 & 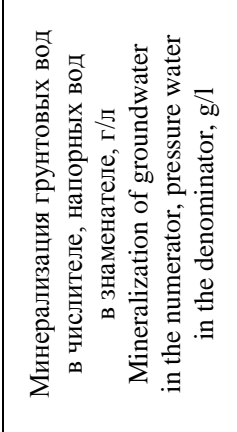 & 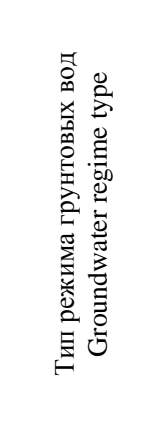 \\
\hline I & - & 20,0 & $5,0-10,0 / 4,6-9,6$ & $1,0-5,0 / 0,5-1,0$ & $\begin{array}{c}\text { Ирригаци- } \\
\text { онный } \\
\text { Irrigation }\end{array}$ \\
\hline & A & 28,0 & $1,5-3,0 / 0,8-1,5$ & $5,0-20,0 / 1,0-5,0$ & $\begin{array}{l}\text { Мелиора- } \\
\text { тивный } \\
\text { Meliorative }\end{array}$ \\
\hline II & Б & 24,0 & $2,0-6,0 / 1,5-4,2$ & $20,0-80,0 / 1,0-10,0$ & $\begin{array}{c}\text { Ирригаци- } \\
\text { онно- } \\
\text { поливной } \\
\text { Irrigation- } \\
\text { watering } \\
\end{array}$ \\
\hline \multirow{2}{*}{ III } & A & 15,0 & $1,0-5,0 / 1,0-3,0$ & $40,0-50,0 / 3,0-15,0$ & $\begin{array}{c}\text { Климатиче- } \\
\text { ский } \\
\text { Climatic } \\
\end{array}$ \\
\hline & Б & 13,0 & $2,0-4,0 / 0,6-2,9$ & $1,0-40,0 / 1,0-20,0$ & $\begin{array}{c}\text { Гидрологи- } \\
\text { ческий } \\
\text { Hydrological }\end{array}$ \\
\hline
\end{tabular}




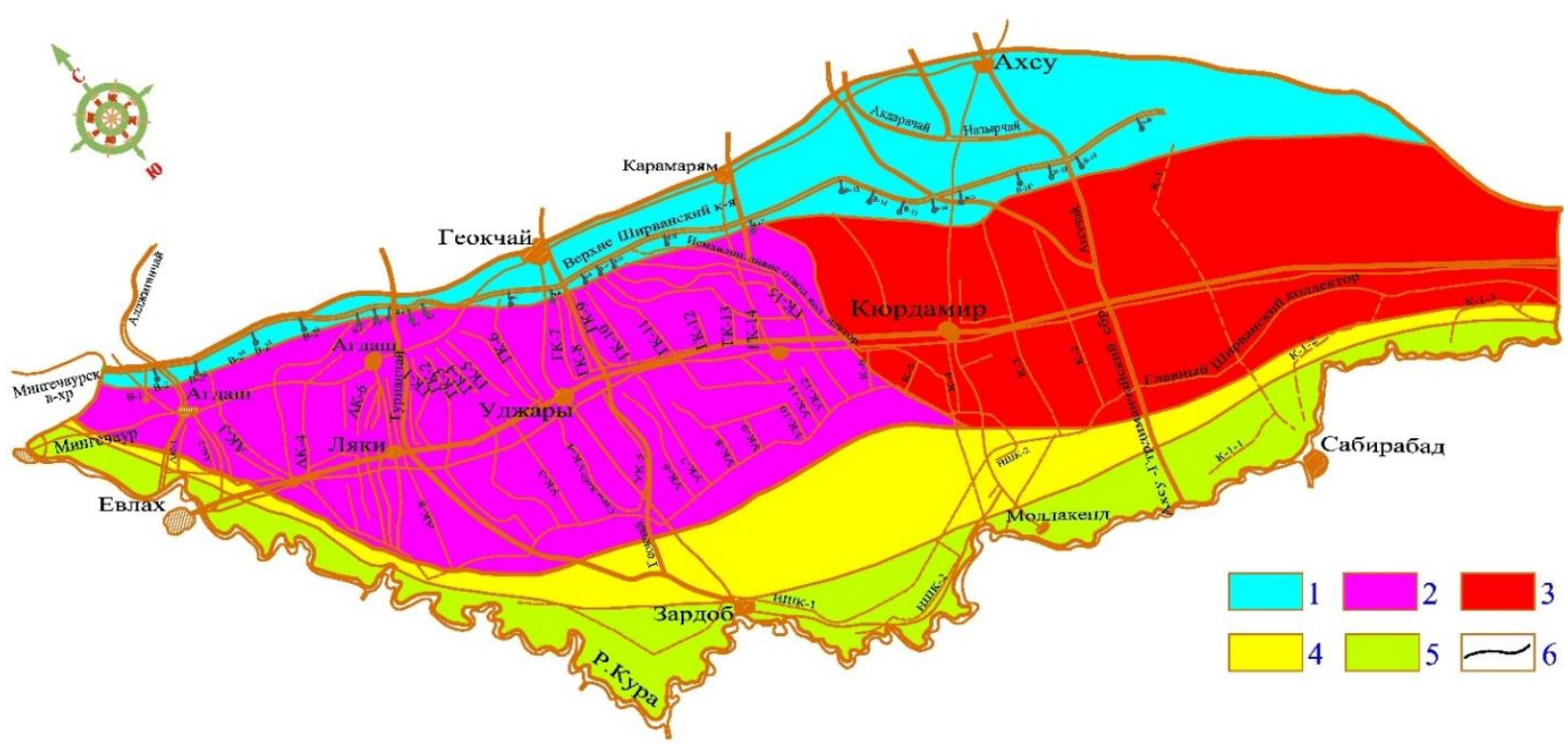

Рис. 3. Схематическая карта гидрогеолого-мелиоративного районирования Ширванской степи (по состоянию на май 2018 г., составлена Ч.Д. Гюльмамедовым; М. 1:100000): районы (I, II, III) и подрайоны (A, Б). 1) I; 2) II A; 3) II Б; 4) III A; 5) III Б; 6-границы гидрогеолого-мелиоративных районов и подрайонов

Fig. 3. Schematic map of hydrogeological-reclamation zoning of the Shirvan steppe (as of May 2018, compiled by Ch.D. Gulmamedov; S. 1:100000): districts (I, II, III) and subdistricts (A, B). 1) I; 2) II A; 3) II B; 4) III A; 5) III B; 6) boundaries of hydrogeological-reclamation regions and subregions

Зона влияния, прилегающая к трассе ВШК, рассматривается как область, характеризующаяся наличием в подавляющей части её территорий разгрузки напорных подземных вод, подпитывающих грунтовые воды. Это определяет общность структуры водно-солевого баланса по всей территории.

Первый район охватывает привершинную часть конусов выноса речных артерий и развита на 20,0 \% от общей площади. Здесь напорное питание ослаблено за счёт дренирующей роли речных долин, происходит формирование подземных вод и их расчленение на напорные и ГВ. Подземный отток, направленный с предгорных зон к реке Куре, наибольший, практически он не оказывает никакого влияния на грунтовые воды и процессы почвообразования. В районе за счёт местных факторов поверхностного увлажнения формируется слабоминерализованные грунтовые воды, дренируемые долинами рек. Первый от поверхности выдержанный водоупор залегает на глубине более 25 м $[6,7,18]$. Водовмещающие породы обладают высокими фильтрационными свойствами с коэффициентом фильтрации 4-10 м/сутки. Минерализация грунтовых вод составляет 1-5 г/л, глубина их залегания 5-10 м. Здесь распространён ирригационный тип режима ГВ. Почвогрунты незасолённые. Возможно дальнейшее освоение района под орошение без сложных гидротехнических мелиораций.

Второй район охватывает среднюю часть конуса выносов речных отложений, где распространены пролювиальные отложения с коэффициентом фильтрации 3-5 м/сутки. Грунтовые воды с минерализацией 5-80 г/л залегают на глубине 1-6 м. Величина напорного питания составляет 3-4 тыс. м³/га. Глубина залегания кровли водоупорной толщи находится в 20-25 м от поверхности земли. Здесь происходит транспорти- ровка грунтовых вод, что оказывает активное влияние на почвообразование. В западной части территории естественный режим засоления нарушается интенсивным орошением и дренажом, а в восточной части - ирригацией и орошением. После реконструкции дренажных сетей для регулирования засоления в западной части требуется в основном эксплуатационные мероприятия, на востоке - строительство новых дренажных сетей на фоне последующих промывок и орошения. Второй район охватывает 55,0 \% от общей площади.

Третий район - это аллювиальная равнина реки Куры, которая развита на 25,0 \% площади. Напорное питание изменяется в пределах 1-3 тыс. м/га в год. Коэффициент фильтрации водовмещающих пород 1-10 м/сутки. Минерализация грунтовых вод изменяется в пределах 1-50 г/л. Грунтовые воды залегают на глубинах 1-5 м, оказывая активное отрицательное влияние на процессы почвообразования. Общее мелиоративное состояние земель неблагоприятное. Для развития орошения требуется организация промывного режима этих земель и промывок на фоне интенсивного дренажа.

На основе характеристики районов можно предложить те или иные мелиоративные мероприятия в связи с развитием орошения $[12,17,23,25]$. Для этого необходимо провести режимные наблюдения и получить более конкретные данные. Внутри районов выделяются характерные подрайоны. Подрайоны выделены по закономерности изменения водно-солевого баланса территории в многолетнем разрезе. Основанием для этого послужили характеристики прироста уровня и увеличения минерализации грунтовых вод, т. е. конкретные параметры, отражающие воздействие результирующего водно-солевого баланса. Перечисленные характеристики позволяют обосновать для 
каждого района и подрайона конкретный состав мелиоративных мероприятий по регулированию водносолевого баланса в связи с развитием орошения.

\section{Заключение}

В течение 60 лет уровень грунтовых вод на территории поднялся более чем на 4,0 м, а их минерализация уменьшилась на 16,0 г/л. Режим подземных вод в основном формируется за счёт орошение земель и дренажа.

При проведении гидрогеолого-мелиоративного районирования провинщия выделена по признакам отнесения к определенной геолого-тектонической структуре; зона - по почвенно-климатическим признакам; районы - по геоморфологическим элементам и литологическому строению толщи до водоупора; подрайоны - по типу и степени засолённости почвогрунтов и режиму грунтовых вод. Выделяется одна провинция - Куринский синклинорий, одна зона с климатом умеренно-тёплых полупустынь и сухих степей с сухим летом, три района и четыре подрайона

Первый район охватывает привершинную часть конусов выноса речных артерий, коэффициент фильтрации водовмещающих пород 4-10 м/сутки, минерализация грунтовых вод 1-5 г/л, а глубина их залегания 6-10 м. Глубина залегания кровли водоупорной толщи более 25,0 м от поверхности земли. Здесь рас-

\section{СПИСОК ЛИТЕРАТУРЫ}

1. Алиев Ф.Ш. Подземные воды Азербайджанской республики, использование запасов и геологические проблемы. - Баку: Чашыоглы, 2000. - 325 с.

2. Ахмедзаде А.Д., Гашимов А.Д. Кадастр мелиоративных и водохозяйственных систем. - Баку: Азернешр, 2006. - 626 с.

3. Гюльмамедов Ч.Д., Джафарлы Ж.В. Режим подземных вод Ширванской степи Азербайджанской республики // Международный журнал «Наука и мир». - 2019. - № 1 (65). - С. 22-26.

4. «Оценка гидрогеолого-мелиоративного условия земель, расположенных в зоне влияние ВШК, и разработка научно обоснованных мероприятий для их улучшения» / Г.А. Хасаев, Д.М. Исмаилов, М.Я. Асадов, П.А. Абдуллаев, Ш.Д. Данялов, Г.М. Магеррамов, А.Г. Рагимова // Годовой отчёт Научнопроизводственного объединения «Гидротехника и Мелиорация» Азербайджана. - Баку, 2019. - 65 с.

5. Куренной В.В., Шпак А.А. Мониторинг геологической среды - основа экологической оценки техногенных изменений геологической среды // Разведка и охрана недр. - 1999. № 12. - С. 46-49.

6. Гюльмамедов Ч.Д. Взаимосвязи поверхностных и подземных вод Ширванской степи Азербайджана // Международный журнал «Наука и мир». - 2018. - № 10 (62). - С. 14-20.

7. Геология Азербайджана. T. VIII. Гидрогеология и инженерная геология / под ред. А. Б. Алекперова. - Баку: Из-во «NaftaPress», 2008. - 368 c.

8. Листенгартен В.А. Формирование ресурсов подземных вод аллювиально-пролювиальных равнин. - Баку: Изд-во «Элм», 1987. - 164 c.

9. Jackson J., Priestley K., Allen M. Active tectonics of the South Caspian Basin // Geophysical Journal International. - 2002. V. 148. - Iss. 2. - Р. 214-245.

10. Гюльмамедов Ч.Д. Влияние техногенной деятельности человека на гидрогеоло-гические условия // Международный журнал «Наука и мир». - 2020. - № 2 (78). - С. 15-19.

11. Куренной В.В., Куренная Л.М., Соколовский Л.Г. Общее гидрогеологическое районирование. Концепции и реализации // Разведка и охрана недр. - 2009. - № 9. - С. 42-48. пространён ирригационный тип режима грунтовых вод. Почвогрунты незасолённые. Возможно дальнейшее освоение района с орошением без сложных гидротехнических мелиораций.

Второй район охватывает среднюю часть конуса выносов речных отложений с коэффициентом фильтрации водовмещающих пород 3-5 м/сутки, минерализацией грунтовых вод 5-60 г/л, глубиной залегания 1,5-6,0 м. Напорное питание 3-4 тыс. м³/га. Глубина залегания кровли водоупорной толщи 20,0-25,0 м от поверхности земли. После реконструкции дренажных сетей для регулирования засоления в западной части требуются в основном эксплуатационные мероприятия, на востоке - строительство новых дренажных сетей на фоне последующих промывок и орошения.

Третий район - это аллювиальная равнина реки Куры, напорное питание изменяется в пределах 1-3 тыс. $\mathrm{m}^{3} /$ га в год при практически отсутствующем подземном оттоке. Первый от поверхности выдержанный водоупор залегает на глубинах 17-20 м, коэффициент фильтрации водовмещающей породы 1-10 м/сутки. Минерализация грунтовых вод пёстрая, изменяется в пределах 1-50 г/л. Грунтовые воды залегают на глубинах 1-3 м. Для развития орошения требуется организация его промывного режима и промывок на фоне интенсивного дренажа.

12. Алимов А.К. Гидрогеологические процессы и количественные оценки источников формирования элементов водно-солевого баланса грунтовых вод для обоснования гидрогеологомелиоративных прогнозов. - Баку: Элм, 2001. - 294 с.

13. Barthel R.A. Call for more fundamental science in regional hydrogeology // Hydrogeology Journal. - 2014. - V. 22. - № 3. P. 507-510.

14. Montcoudiol N., Molson J., Lemieux J.-M. Groundwater geochemistry of the Outaouais Region (Quebec, Canada): a regional-scale study // Hydrogeology Journal. - 2014. - V. 23. № 2. - P. 377-396.

15. Wang J., Zuo R., Caers J. Dickovering geochemical patterns by faktor-based cluster analysis // Journal of Geochemical Exploration. - 2017. - V. 181. - P. 106-115.

16. Groundwater geochemistry and microbial community structure in the aquifer transition from volcanic to alluvial areas / S. Amalfitano, A.D. Bon, A. Zoppini, S. Ghergo, S. Fazi, D. Parrone, P. Casella, F. Stano, E. Preziosi // Water Resources. 2014. - V. 65. - P. 384-394.

17. Burnett W.C. Quantifying submarine groundwater discharge in the coastal zone via multiple methods // Science of the Total Environment. - 2006. - P. 498-543.

18. Исрафилов Ю.Г. Научно-технические основы регулирования подземного стока на конусах выноса // Современные проблемы рационального и комплексного использования водных ресурсов: Труды АзНИИ Водных проблем. - Баку: 2000. C. $83-85$.

19. Geochemical and magnetic properties of sediments as pollution indicators. Case study: Suquía river, Córdoba, Argentina / L.D. Sepúlveda, K.L. Lecomte, A.I. Pasquini, E.G. Mansilla, M.A.E. Chaparro // Revista Mexicana de Ciencias Geologicas. 2019. - V. 36. - P. 183-194.

20. Исрафилов Ю.Г. Формирование, прогноз и рациональное использование ресурсов пресных подземных вод предгорных равнин Азербайджанской Республики: автореф. дис. ... д-ра наук. - Баку, 2005. - 48 c.

21. Savichev O.G., Paromov V.V. Chemical composition of glacial meltwaters and river waters within the Aktru river basin (Gornyi Altai) // Geography and Natural Resources. - 2013. - V. 34. № 4. - P. 364-370. 
22. Geochemical distribution of major and trace elements in agricultural soils of Castilla La Mancha (central Spain): finding criteria for baselines and delimiting regional anomalies / S. Bravo, E. García-Ordiales, F.J. García-Navarro, J.Á. Amorós, C. Pérezdelos-Reyes, R. Jiménez-Ballesta, J.M. Esbrí, E.M. García Noguero, P. Higueras // Environmental Science and Pollution Research. 2019. - V. 26. - Iss. 4. - P. 3100-3114

23. Evaluation of geochemical baselines and metal enrichment factor values through high ecological quality reference points: a novel methodological approach / R. Selvaggi, B. Damianić, E. Goretti, M. Pallottini, C. Petroselli, B. Moroni, G. La Porta, D. Cappelletti //
Environmental Science and Pollution Research. - 2020. - V. 27. Iss. 1. - P. 930-940

24. Кац Д.М., Шестаков В.М. Мелиоративная гидрогеология. - М. Изд-во МГУ, 1981. - 296 с.

25. Cronmiller J.G., Noble B.F. The discontinuity of environmental effects monitoring in the Lower Athabasca region of Alberta, Canada: institutional challenges to long-term monitoring and cumulative effects management // Environmental Reviews. - 2018. - V. 26. - Iss. 2. - P. 169-180.

\section{Информация об авторах}

Гюльмамедов Ч.Д. оглы, кандидат геолого-минералогических наук, доцент, ведущий научный сотрудник Азербайджанского научно-производственного объединения «Гидротехника и Мелиорация». 
UDK 626/627 626.86.004.67

\title{
INFLUENCE OF THE VERKHE-SHIRVAN CANAL ON CHANGES OF HYDROGEOLOGICAL AND MELIORATIVE CONDITIONS OF THE SHIRVAN STEPPE OF AZERBAIJAN
}

\author{
Chingiz Cahangir oglu Gulmammadov, \\ gcin56@mail.ru
}

Azerbaijan Scientific and Production Association «Hydraulic engineering and melioration», 324, I. Dadashov street, Baku, 1130, Azerbaijan.

The relevance of the research consists in studying the change of the level, chemical content, conditions of formation, regime of groundwater and salinity of soils under the influence of anthropogenic factors over a long period of time and in this background the formation of hydrogeological-meliorative conditions.

The main aim is to study the change of the hydrogeological-meliorative conditions under the anthropogenic influence in the territories of its effect zone after putting into operation Verkhne-Shirvan canal.

Objects of the research are the effect zone of the Verkhne-Shirvan canal of Shirvan plain of the Republic of Azerbaijan.

Methods. Based on the results of research conducted by the author on the level, mineralization degree of groundwater and salinity of soils over a long period of time and the data collected, the hydrogeological-meliorative division into districts was carried out.

Results. Due to the operation of the Verkhne-Shirvan canal, the level of groundwater, the degree of mineralization, the chemical content and the salinity and chemical content of the salts have changed in its effect zone. From 1958 to 2018 groundwater in this area rose by more than 4,0 $\mathrm{m}$ due to irrigation reclamation, and their mineralization degree decreased by $16,0 \mathrm{~g} / \mathrm{l}$ due to infiltration of surface water and removal of mineralized water through drainage. The groundwater regime in the whole is formed by irrigation of lands and drainage. Hydrogeological-meliorative zoning of the area was carried out based on the results of research on changes in the level of subsoil water, chemical composition and salinity of soils and analysis of collected archival materials. A province-the Kur synclinorium, one zone, semisteppe with temperate-hot climate and dry-steppe with dry climate, three districts and four sub-districts are allocated. The first region covers the ends of the cones of river networks. The filtering coefficient of the rocks of the water-bearing horizons is $4-10 \mathrm{~m} / \mathrm{day}$, the degree of mineralization of groundwater is 1-5 g/l, their slope depth is 6-10 $\mathrm{m}$. The second area covers the middle parts of the cones of the rivers, the filtering coefficient of proluvial sediments varies in the range of 3-5 $\mathrm{m} /$ day, the degree of mineralization of groundwater is 5-6 g/l their slope depth is 1,5-6,0 $\mathrm{m}$. The third region covers the alluvial plain of the Kura River. The filtering coefficient of the rocks where the water is located reaches $1-10 \mathrm{~m} / \mathrm{day}$, the degree of mineralization of groundwater increases to 1-50 $\mathrm{g} / \mathrm{l}$, the slope depth is 1-3 $\mathrm{m}$.

\section{Key words:}

Impact, canal, subsoil waters, mineralization, chemical composition, ground water level, salting, land reclamation division into districts.

\section{REFERENCES}

1. Aliev F.Sh. Podzemnye vody Azerbaidzhanskoy respubliki, ispolzovanie zapasov i geologicheskie problemy [Underground waters of the Azerbaijan Republic, use of reserves and geological problems]. Baku, Chashyogly Publ., 2000. 325 p.

2. Ahmad-zada A.D., Khashimov A.C. Kadastr podzemnykh vodokhozyaystvennykh sistem [Inventory of underground and water management systems]. Baku, Azernashr Publ., 2006. 626 p.

3. Gulmammadov Ch.D., Zhafarly Zh.V. Groundwater regime of the Shirvan steppe of the Azerbaijan Republic. International journal «Science and World», 2019, vol. I, no. 1 (65), pp. 22-26. In Rus.

4. Khasaev Q.A., Ismailov S.M., Asadov M.Ya., Abdullaev P.A., Danyalov Sh.D., Magerramov G.M., Rakhimova A.G. Otsenka gidrogeologo-mileorativnogo usloviya zemel, raspolozhennykh $v$ zone vliyaniya VSHK, i razrabotka nauchno obosnovannykh meropriyatiy dla ikh uluchsheniya [Assessment of the hydrogeological and milleorative conditions of lands located in the zone of influence of the MSC, and development of scientifically based measures to improve them]. Azerbaijan Hydrotechnical and Melioration Scientific Production Association annual report. Baku, 2019. $65 \mathrm{p}$

5. Kurennoy V.V., Shpak A.A. Monitoring geologicheskoy sredy osnova ekologicheskoy otsenki tekhnogennykh izmeneniy geologicheskoy sredy [Monitoring of the geological environment the basis for environmental assessment of technogenic changes in the geological environment]. Exploration and protection of mineral resources, 1999, no. 12, pp. 46-49.

6. Gulmammadov Ch.D. Interrelation of surface and underground waters of the Shirvan steppe of Azerbaijan. International scientific journal, 2018, vol. II, no. 10 (62), pp. 14-20. In Rus.

7. Gologiya Azerbaydzhana. T. VIII. Gidrogeologiya i injenernaya geologiya [Geology of Azerbaijan. Vol. VIII. Hydrogeology and engineering geology]. Ed. by A.B. Alekperov. Baku, Nafta-Press 2008. $368 \mathrm{p}$.

8. Listengarten V.A. Formirovanie resursov podzemnykh vod allyuvialno-prollyuvialnykh ravnin [Formation of groundwater resources of alluvial and proluvial plains]. Baku, Elm Publ. house, 1987. $164 \mathrm{p}$

9. Jackson J., Priestley K., Allen M. Active tectonics of the South Caspian Basin. Geophysical Journal International, 2002, vol. 148, Iss. 2, pp. 214-245.

10. Gulmammadov Ch.D. Influence of technogenic activity of a man on hydrogeological conditions. International scientific journal, 2020, vol. I, no. 2 (78), pp. 15-19. In Rus.

11. Kurennaya V.V., Kurennaya L.M., Sokolovsky L.G. Obshchee gidrogeologicheskoe rayonirovanie [General hydrogeological zoning]. Kontseptsiya i realizatsiya. Razvedka $i$ okhrana nedr, 2009, no. 9, pp. 42-48.

12. Alimov A.K. Gidrogeolohicheskie protsessy i kolichestvennye otsenki istochnikov formirovaniya elementov vodno-solevogo balansa gruntovykh vod dlya obosnovaniya gidrogeologomeliorativnykh prognozov [Hydrogeological processes and quantitative assessments of the sources of formation of the elements of the water-salt balance of soil and water for the substantiation of hydrogeological and reclamation assessments]. Baku, Elm Publ., 2001. 294 p.

13. Barthel R.A. Call for more fundamental science in regional hydrogeology. Hydrogeology Journal, 2014, vol. 22, no. 3, pp. 507-510.

14. Montcoudiol N., Molson J., Lemieux J.-M. Groundwater geochemistry of the Outaouais Region (Quebec, Canada): a regional-scale study. Hydrogeology Journal, 2014, vol. 23, no. 2, pp. 377-396.

15. Wang J., Zuo R., Caers J. Dickovering geochemical patterns by faktor-based cluster analysis. Journal of Geochemical Exploration, 2017, no. 181 , pp. $106-115$. 
16. Amalfitano S., Bon A.D., Zoppini A., Ghergo S., Fazi S., Parrone D. Casella P., Stano F., Preziosi E. Groundwater geochemistry and microbial community structure in the aquifer transition from volcanic to alluvial areas. Water Resources, 2014, vol. 65, pp. 384 394.

17. Burnett W.C. Quantifying submarine groundwater discharge in the coastal zone via multiple methods. Science of the Total Environment, 2006, pp. 498-543.

18. Israfilov Yu.G. Nauchno-tekhnicheskie osnovy regulirovaniya podzemnogo stoka na konusakh vynosa. Sovremennye problemy ratsionalnogo i kompleksnogo ispolzovaniya vodnykh resursov [Scientific and technical foundations for the regulation of underground runoff on alluvial cones. Modern problems of rational and complex use of water resources]. Trudy AzNII vodnykh problem. Baku, 2000. pp. 83-85.

19. Sepúlveda L.D., Lecomte K.L., Pasquini A.I., Mansilla E.G., Chaparro M.A.E. Geochemical and magnetic properties of sediments as pollution indicators. Case study: Suquía river, Córdoba, Argentina. Revista Mexicana de Ciencias Geologicas, 2019, vol. 36, pp. 183-194.

20. Israfilov Yu.G. Formirovanie, prognoz i ratsionalnoe ispolzovanie resursov presnykh podzemnykh vod predgornykh ravnin Azerbaidzhanskoy respubliki. Avtoreferat Dis. Dokt. nauk [Formation, forecast and rational use of resources fresh underground waters of waste plains of the Republic of Azerbaijan. Cand. Diss. Abstract]. Baku, 2005. 48 p.
21. Savichev O.G., Paromov V.V. Chemical composition of glacial meltwaters and river waters within the Aktru river basin (Gornyi Altai). Geography and Natural Resources, 2013, vol. 34, no. 4, pp. 364-370.

22. Bravo S., García-Ordiales E., García-Navarro F.J., Amorós J.Á., Pérezde-los-Reyes C., Jiménez-Ballesta R., Esbrí J.M., García Noguero E.M., Higueras P. Geochemical distribution of major and trace elements in agricultural soils of Castilla La Mancha (central Spain): finding criteria for baselines and delimiting regional anomalies. Environmental Science and Pollution Research, 2019, vol. 26, Iss. 4, pp. 3100-3114.

23. Selvaggi R., Damianić B., Goretti E., Pallottini M., Petroselli C., Moroni B., La Porta G., Cappelletti D. Evaluation of geochemical baselines and metal enrichment factor values through high ecological quality reference points: a novel methodological approach. Environmental Science and Pollution Research, 2020, vol. 27, Iss. 1, pp. 930-940.

24. Kats D.M., Shestakov V.M. Meliorativnaya gidrogeologiya [Reclamation hydrogeology]. Moscow, Moscow State University Publ. house, 1981. $296 \mathrm{p}$

25. Cronmiller J.G., Noble B.F. The discontinuity of environmental effects monitoring in the Lower Athabasca region of Alberta. Canada: institutional challenges to long-term monitoring and cumulative effects management. Environmental Reviews, 2018, vol. 26, Iss. 2, pp. 169-180

Received: 20 September 2021.

\section{Information about the author}

Chingiz Cahangir oglu Gulmammadov, Dr. Sc., assistant professor, Azerbaijan Scientific and Production Association «Hydraulic engineering and melioration». 